\title{
Treatment Pathway and Patterns of Clozapine Prescribing for Schizophrenia in New Zealand
}

\author{
Amanda J Wheeler
}

$\mathrm{T}_{\mathrm{c}}^{\mathrm{h}}$ he second-generation antipsychotic clozapine has consistently been shown to be the most effective antipsychotic in treatment-resistant schizophrenia in controlled trials, ${ }^{1,2}$ meta-analysis, ${ }^{3}$ and longterm effectiveness studies.,

In addition to its superior efficacy in treatment-resistant schizophrenia, clozapine offers clinical advantages over other antipsychotics. These include a low risk of extrapyramidal symptoms ${ }^{6}$ (reflected in its approval in most countries for use in people intolerant of other antipsychotics, particularly tardive dyskinesia); reduction of suicide in schizophrenia ${ }^{7}$ (approved for this indication in the US); and reduction in the frequency and duration of hospital admissions. ${ }^{8,9}$ This research evidence has led current clinical practice guidelines to recommend that clozapine be considered at the earliest opportunity for people with treatment-resistant schizophrenia. This is defined as a lack of satisfactory clinical response to trials (with recommended treatment duration $6-8 \mathrm{wk}$ ) of at least 2 antipsychotics (at least 1 of which should be a non-clozapine second-generation antipsychotic such as risperidone, olanzapine, or quetiapine). ${ }^{10-12}$

However, clozapine is associated with other problematic effects such as sedation, hypersalivation, weight gain, constipation, insulin resistance, and diabetes, ${ }^{13,14}$ and, more rarely, risks of cardiac adverse events such as myocarditis and cardiomy-

Author information provided at the end of the text.
OBJECTIVE: To describe the treatment pathway and patterns of clozapine use in patients with schizophrenia, including coprescribed psychotropic medications, and compare the extent of coprescribing of clozapine with that of non-clozapine schizophrenia treatment in community mental health services in the Auckland and Northland regions of New Zealand.

METHODS: A retrospective chart review was conducted for adult outpatients receiving care from community mental health services on October 31, 2004. Data collected for all patients prescribed an antipsychotic included demographics (sex, age, ethnicity); principal diagnosis (Diagnostic and Statistical Manual of Mental Disorders, 4th edition); comorbid conditions; duration of mental illness; psychiatric admissions; and treatment information (psychotropic medications, with dose and route of administration). If clozapine had been started after the introduction of full government prescription subsidy (February 1999), additional data, including year of initiation and prior antipsychotic history, were collected. Analysis included all outpatients with a diagnosis of schizophrenia (including schizoaffective disorder).

RESULTS: Antipsychotics were prescribed for 2796 schizophrenia patients; $32.8 \%$ were prescribed clozapine, with a mean dose of $372 \mathrm{mg} /$ day and an average duration of illness of 9.7 years before starting clozapine. Patients who had started treatment after clozapine was funded by the government $(59.3 \%)$ had received a median of 3 antipsychotic drugs prior to starting clozapine; most of the treatment regimens included 1 second-generation antipsychotic (91.2\%). Clozapine patients were less likely to be coprescribed another antipsychotic compared with non-clozapine patients $(11.7 \%$ vs $17.6 \% ; p<0.001)$. Both the clozapine and nonclozapine groups had a low total number of psychotropic medications prescribed (median 2); for clozapine patients, the second drug was most likely to be for treatment of hypersalivation.

CONCLUSIONS: Outpatients with treatment-resistant schizophrenia were prescribed clozapine at expected rates; however, treatment was delayed longer than recommended. There is some evidence that access to clozapine for treatmentresistant schizophrenia has improved, possibly as the result of the introduction of government subsidy, guideline dissemination, or increasing experience of clinicians with use of clozapine. In this real-world environment, the number of concomitant psychotropic medications for outpatients with schizophrenia was found to be low; when used concomitantly with clozapine, they were most commonly used to manage adverse effects.

KEY WORDS: audit, clozapine, prescribing, schizophrenia.

Ann Pharmacother 2008;42:852-60.

Published Online, 13 May 2008, www.theannals.com, DOI 10.1345/aph.1K662 
opathy. ${ }^{15,16}$ It is the significant hematologic risks (severe neutropenia and agranulocytosis) that have necessitated the need for regular blood testing and registration with a national monitoring database in most countries that use clozapine. ${ }^{14}$ In New Zealand, weekly white blood cell counts are required for the first 18 weeks of therapy, followed by monthly testing thereafter. ${ }^{17,18}$ Guidance for regular monitoring of metabolic and cardiac adverse events for all antipsychotic medications has also been outlined by the New Zealand Mental Health Metabolic Working Group Initiative. ${ }^{19}$

Estimates of the number of people with treatment-resistant schizophrenia who are expected to benefit from clozapine range from $25 \%$ to $50 \%$. Previous research indicated that clozapine is underused..$^{20,21}$ Similarly, other research suggested that treatment is delayed for longer than is desirable to improve clinical, social, and functional outcomes; that is, clozapine is not prescribed as soon as 2 other antipsychotics have failed. ${ }^{22}$ Factors affecting the use of clozapine may include issues relating to patient consent, patient adherence to monitoring, adverse effects, the increasing availability of other second-generation antipsychotics, ${ }^{21,23,24}$ and cost of this medication.

Although clozapine was registered for use in New Zealand in early 1993, funding was restricted to the discretionary use of a hospital's budget intended for inpatient treatment only. Difficulties for patients in gaining access to clozapine treatment were highlighted in the mid-1990s 25 and, in February 1999, clozapine became a fully funded medicine for all patients in the community or hospital setting. National underprescribing of clozapine continued to be reported, ${ }^{\mathbf{2 6}}$ and steps were taken to monitor its use regionally. At that time, national data extracts of dispensing data from electronic pharmacy databases did not provide information about the number of individuals taking a particular medication or about the individual's diagnosis. This study was therefore set up with the aim of using clinical audit and feedback ${ }^{27}$ as a tool to compare everyday best practice with recommended practice for adults engaged with a community mental health center (CMHC) in Auckland (the largest city in New Zealand) and Northland (a mixed urban and rural region north of Auckland).

This paper reports first on the treatment pathway and pattern of clozapine prescribing in schizophrenia, and second on the extent to which other psychotropic drugs were coprescribed with clozapine. The coprescription of psychotropic drugs with clozapine in patients with schizophrenia is compared with schizophrenia patients prescribed alternative antipsychotic treatment.

\section{Methods}

\section{STUDY SAMPLE}

This cross-sectional retrospective study included all outpatients (aged 15-64 y) attending a CMHC in the Auck- land and Northland regions on October 31, 2004. The CMHCs are located outside the hospital setting, spread geographically across these regions, and managed by 4 District Health Boards (DHBs; DHB-A, -B, -C, and -D). The catchment area's population aged $15-64$ years was 872,718 people, based on Census 2001 data. ${ }^{28-31}$ Only outpatients with a diagnosis of schizophrenia (including schizoaffective disorder) who were prescribed an antipsychotic were included in this analysis $(\mathrm{N}=2796){ }^{32}$

\section{DATA COLLECTION}

Study data were extracted by a trained senior psychiatric research nurse from the paper and/or electronic clinical file used at each CMHC and from each DHB's patient information management system. Data were entered by a clerical assistant into a custom-designed Microsoft Access database with predetermined response options to ensure data quality and facilitate analysis. Data collected included demographics (sex, age, ethnicity), principal diagnosis, comorbid conditions, duration of mental illness (time, in years, from first contact with a treatment provider until 2004), psychiatric admission history, and treatment data (psychotropic medication, with total daily dose and route of administration). The principal Axis I diagnosis (Diagnostic and Statistical Manual of Mental Disorders, 4 th ed. ${ }^{32}$ ) documented at the psychiatric assessment closest to October 31, 2004, was recorded as the major mental disorder (these assessments are usually conducted every 3 months to coincide with prescription requirements). Axis I and II comorbidities were recorded if documented at the psychiatric assessment closest to the study review point. Documented physical health comorbidities were recorded, as well as medications prescribed concurrently (database allowed recording of 2 additional Axis I, 2 Axis II, and up to 8 Axis III comorbidities). Other information was extracted from clinical summaries, case reviews, discharge summaries, and the multidisciplinary progress notes recorded for the 3 months on either side of the review point. Psychiatric admission history was verified with the National Health Events database maintained by the National Health Information Service.

All psychotropic data (including antipsychotics, antidepressants, mood stabilizers, sedative-hypnotics, and drugs used for management of neurologic adverse effects of antipsychotics) were recorded from the medication chart and verified in the body of the clinical notes or with duplicate copies of the prescription wherever possible. For patients prescribed clozapine, the year of initiation was also recorded. When clozapine initiation was from 1999 onward (the year community funding became available), information about the type and number of antipsychotics prescribed prior to clozapine was collected. The number of antipsychotic treatments was defined as the number of different antipsychotics prescribed regularly at a therapeutic antipsychotic 
dose for a minimum of 6 weeks. If the drug was used more than once, it was counted as a single antipsychotic treatment. Where there was a clearly documented break in clozapine treatment ( $>12 \mathrm{wk}$, and alternative antipsychotic treatment was prescribed), the clozapine restart date was recorded. The national clozapine registration database was used to verify the treatment start/restart date(s) and discontinuation date and reason for discontinuation where relevant. For the purposes of comparison, antipsychotic doses were converted into chlorpromazine equivalents (CPZe). The methodology used for this is described elsewhere. ${ }^{33}$

The study was approved by the Auckland Regional Ethics Committee (AKL2000/065).

\section{DATA ANALYSIS}

Data analyses were conducted using SPSS version 15 (SPSS, Chicago, IL). Continuous variables were compared between groups using independent $t$-tests or analysis of variance. Discrete variables were analyzed using $\chi^{2}$ tests. When sample distributions did not satisfy assumptions of normality (eg, age, duration of illness, psychiatric admissions), nonparametric tests were used (Mann-Whitney $U$ or Kruskal-Wallis) or the variable was log transformed for analysis (eg, antipsychotic dose). Logistic regression was used to investigate variables associated with 2 outcome measures: pre-clozapine treatment duration (year of first contact with a treatment provider to year clozapine started) and antipsychotic coprescription with clozapine. To minimize the type I error associated with multiple comparisons, the threshold required to demonstrate statistical significance was set at $p$ less than 0.01

\section{Results}

There were 2796 outpatients with schizophrenia or schizoaffective disorder being treated with an antipsychotic in the 4 mental health services in October 2004. Within this group, 917 (32.8\%) were prescribed clozapine. The clozapine group had a mean age of 37.1 years; more than two-thirds were male, half were identified as European, and, on average, they had been unwell for 15 years.

Comparisons between the clozapine and non-clozapine treatment groups are shown in Table 1. There were more females in the non-clozapine group. The ethnicity profile also differed, with fewer European and Asian and more Māori and Pacific people treated with clozapine. Patients prescribed clozapine had been unwell for longer and were less likely to have comorbid mental disorder(s), primarily seen with lower rates of movement disorders diagnosed as Axis I neuroleptic-induced disorders (Table 1). There was no significant difference between groups in the proportion with a comorbid Axis II disorder. Physical comorbidity was grouped $(0,1,2-4$, and $\geq 5$ conditions) for analysis.
Again, there was no significant difference between groups, although patients treated with clozapine were found to have higher rates of gastrointestinal conditions.

The average daily dose of clozapine was $372 \mathrm{mg}$ (median 350, SD 152, range 50-900). Average daily doses did not vary significantly across the 4 DHBs (clozapine dose $\log$ transformed $\mathrm{F}_{3,913}=0.77 ; \mathrm{p}=0.29$ ).

\section{PATHWAY TO CLOZAPINE TREATMENT}

Almost the entire clozapine group (99.6\%) had data that allowed calculation of the duration between year of first contact with a treatment provider and the clozapine starting year. Thirty-seven percent had started clozapine within 5 years of first contact with a provider $(18.3 \%$ in $\leq 2 \mathrm{y}$, $18.6 \%$ in $3-5 \mathrm{y}$ ), $24.8 \%$ within $6-10$ years, and $38.3 \%$ more than 10 years after first contact. The mean pre-clozapine treatment duration was 9.7 years (median 8; SD 7.8; range $0-43$ ). Longer pre-clozapine treatment duration was found in older patients (aged $\geq 50 \mathrm{y}$, mean $20.4 \mathrm{y}$; aged 30-49 y, $10.1 \mathrm{y}$; aged 15-29 y, $3.2 \mathrm{y} ; \mathrm{p}<0.001)$. It was also longer in European patients (mean 11.3 y; Māori, 8.7 y; Pacific, $7.8 \mathrm{y}$; Asian, $6.7 \mathrm{y}$; $\mathrm{p}<0.001$ ), and for patients who started clozapine treatment before it was funded in 1999 (mean 10.5 vs. $9.2 \mathrm{y} ; \mathrm{p}<0.001$ ). There was no significant difference in the pre-clozapine treatment duration between sexes $(p=0.285)$ or DHBs $(p=0.107)$.

Full government prescription subsidy for clozapine started in February 1999; 59.3\% ( $\mathrm{n}=544)$ started clozapine after this date. A history of antipsychotic treatment was available for 533 of these patients $(98.0 \%)$. Figure 1 shows the distribution of patients by the number of antipsychotic treatments prior to starting clozapine. The average number of antipsychotics prescribed was 3.5 (median 3.0, SD 1.7, range 1-10). The majority had been treated with an oral second-generation antipsychotic (91.2\%), 61.9\% were prescribed at least one oral first-generation antipsychotic, and $46.7 \%$ were prescribed a depot antipsychotic before the switch to clozapine. Only 39 patients had been treated with all 3 oral second-generation antipsychotics available in New Zealand at the time of the audit (risperidone, olanzapine, quetiapine) before starting clozapine.

\section{COPRESCRIBED MEDICATION}

\section{Antipsychotic}

Of the clozapine group, 107 (11.7\%) were concurrently prescribed at least one other antipsychotic (Table 2). Two patients were regularly coprescribed 2 antipsychotics in addition to clozapine. Twenty-seven of those prescribed combinations were with first-generation antipsychotics, 5 of which were depot antipsychotics. Clozapine was coprescribed with another second-generation antipsychotic in 82 patients. The average augmentation doses of the copre- 
scribed antipsychotics are shown in Table 2; these data indicate that most were prescribed at doses below those regarded as therapeutic antipsychotic doses (300-600 mg/day CPZe).

The rates of antipsychotic polytherapy varied across the 4 health services, with a trend for higher rates in DHB-D patients (21.6\% vs DHB-A, 7.3\%; DHB-B, 13.2\%; DHB$\mathrm{C}, 13.6 \% ; \mathrm{p}=0.011)$. There was also some evidence to support differences based on pre-clozapine treatment duration, although these differences did not reach statistical significance (duration $>10 \mathrm{y}, 14.2 \%$ polytherapy; duration $\leq 2$ $\mathrm{y}, 8.5 \%$ polytherapy; $\mathrm{p}=0.058$ ). Combination antipsychotic prescription was not associated with sex $(\mathrm{p}=0.559)$, ethnicity $(p=0.856)$, or age group $(p=0.139)$.

When rates of antipsychotic polytherapy were compared, there was a reduced likelihood of coprescription of another antipsychotic in the clozapine versus non-clozapine group (11.7\% vs $17.6 \% ; \chi^{2} 16.5$; df $=1$; $p<0.001$ ).

\section{Other Coprescribed Medication}

Overall, the clozapine group was prescribed an average of 1.83 psychotropic medications including the antipsychotic (SD 0.95; median 2; range 1-6). Comparison with the non-clozapine group showed no significant difference (mean 1.93; SD 1.07; median 2; range 1-7) (Mann-Whitney $U \mathrm{p}=0.125)$.

Table 3 shows the other psychotropics coprescribed with clozapine. When rates of coprescription of other psychotropics were compared with the non-clozapine treatment group, there was an increased likelihood of being prescribed a medication to manage adverse effects with clozapine $(25.1 \%)$ versus non-clozapine treatment $(19.0 \%)$ $\left(\chi^{2} 13.95 ; \mathrm{df}=1 ; \mathrm{p}<0.001\right)$. This difference is predominantly due to the use of terazosin (an $\alpha_{1}$-antagonist), which is prescribed specifically for clozapine-induced hypersalivation. ${ }^{34}$ Overall, there was no significant difference in rates of anticholinergics prescribed between the clozapine

\begin{tabular}{|c|c|c|c|}
\hline Parameter & Clozapine & $\begin{array}{c}\text { Other } \\
\text { Antipsychotic }\end{array}$ & Statistics \\
\hline $\begin{array}{l}\text { Sex, } \mathrm{n}(\%) \\
\text { male } \\
\text { female }\end{array}$ & $\begin{array}{l}\mathrm{n}=917 \\
652(71.1) \\
265(28.9)\end{array}$ & $\begin{array}{l}\mathrm{n}=1879 \\
1187(63.2) \\
692(36.8)\end{array}$ & $\chi^{2} 17.21, d f=1, p<0.001$ \\
\hline $\begin{array}{l}\text { Age }(y) \\
\text { mean } \pm \text { SD } \\
\text { median (range) }\end{array}$ & $\begin{array}{l}\mathrm{n}=917 \\
37.1 \pm 10.1 \\
36(18-68)\end{array}$ & $\begin{array}{l}n=1879 \\
40.2 \pm 11.7 \\
40(18-80)\end{array}$ & Mann-Whitney $U, p<0.001$ \\
\hline $\begin{array}{l}\text { Ethnicity, } \mathrm{n}(\%) \\
\text { European } \\
\text { New Zealand Māori } \\
\text { Pacific Nations } \\
\text { Asian } \\
\text { other }\end{array}$ & $\begin{array}{l}\mathrm{n}=917 \\
443(48.3) \\
271(29.6) \\
168(18.3) \\
29(3.2) \\
6(0.7)\end{array}$ & $\begin{array}{l}\mathrm{n}=1879 \\
942(50.1) \\
479(25.5) \\
319(17.0) \\
114(6.1) \\
25(1.3)\end{array}$ & $\chi^{2} 17.55, d f=4, p=0.002$ \\
\hline $\begin{array}{l}\text { Duration of illness }(y) \\
\text { mean } \pm \text { SD } \\
\text { median (range) }\end{array}$ & $\begin{array}{l}\mathrm{n}=906 \\
14.7 \pm 8.9 \\
13.0(0-49)\end{array}$ & $\begin{array}{l}n=1800 \\
13.9 \pm 10.3 \\
12.0(0-54)\end{array}$ & Mann-Whitney $U, p<0.001$ \\
\hline $\begin{array}{l}\text { Comorbidity Axis I, }{ }^{\mathrm{b}} \mathrm{n}(\%) \\
\text { SUD } \\
\text { anxiety } \\
\text { NID } \\
\text { other }\end{array}$ & $\begin{array}{l}\mathrm{n}=187(20.4) \\
121(13.2) \\
28(3.1) \\
22(2.4) \\
22(2.4)\end{array}$ & $\begin{array}{l}\mathrm{n}=480(25.5) \\
311(16.6) \\
49(2.6) \\
92(4.9) \\
58(3.1)\end{array}$ & $\begin{array}{l}\chi^{2} 14.38, d f=2, p=0.001 \\
\chi^{2} 5.31, d f=1, p=0.021 \\
\chi^{2} 0.46, d f=1, p=0.499 \\
\chi^{2} 9.83, d f=1, p=0.002 \\
\chi^{2} 1.05, d f=1, p=0.306\end{array}$ \\
\hline $\begin{array}{l}\text { Comorbidity Axis II, }{ }^{c} \text { (\%) } \\
\text { ID } \\
\text { PD }\end{array}$ & $\begin{array}{l}n=79(8.6) \\
55(6.0) \\
27(2.9)\end{array}$ & $\begin{array}{l}\mathrm{n}=175(9.3) \\
124(6.6) \\
54(2.9)\end{array}$ & $\begin{array}{l}\chi^{2} 1.44, d f=2, p=0.49 \\
\chi^{2} 0.37, d f=1, p=0.542 \\
\chi^{2} 0.01, d f=1, p=0.917\end{array}$ \\
\hline $\begin{array}{l}\text { Comorbidity Axis III, }{ }^{d} \mathrm{n}(\%) \\
\text { gastrointestinal } \\
\text { endocrine } \\
\text { respiratory } \\
\text { neurologic } \\
\text { cardiac } \\
\text { other }\end{array}$ & $\begin{array}{l}\mathrm{n}=397(43.3) \\
122(13.3) \\
89(9.7) \\
85(9.3) \\
84(9.2) \\
75(8.2) \\
162(17.7)\end{array}$ & $\begin{array}{l}\mathrm{n}=743(39.5) \\
173(9.2) \\
202(10.8) \\
147(7.8) \\
172(9.2) \\
136(7.2) \\
305(16.2)\end{array}$ & $\begin{array}{l}\chi^{2} 4.91, \mathrm{df}=3, p=0.178 \\
\chi^{2} 10.96, \mathrm{df}=1, p=0.001 \\
\chi^{2} 0.72, \mathrm{df}=1, p=0.396 \\
\chi^{2} 1.69, \mathrm{df}=1, p=0.193 \\
\chi^{2} 0.001, \mathrm{df}=1, p=0.996 \\
\chi^{2} 0.78, \mathrm{df}=1, p=0.377 \\
\chi^{2} 0.91, \mathrm{df}=1, p=0.340\end{array}$ \\
\hline $\begin{array}{l}\text { ID = intellectual disability; NID = neuroler } \\
\text { a } N=2796 \text {. } \\
\text { bPatients could have } 2 \text { other Axis I disorc } \\
\text { cPatients could have } 2 \text { Axis II disorders. } \\
\text { dPatients could have up to } 8 \text { Axis III cono }\end{array}$ & $\begin{array}{l}\text { d disorder; PD } \\
=\text { other mood, } \\
\text { er = oncologica }\end{array}$ & $\begin{array}{l}\text { y disorder; SUD } \\
\text { cognitive, and } \\
\text { ther physical dis }\end{array}$ & $\begin{array}{l}\text { e use disorder. } \\
\text { ders. }\end{array}$ \\
\hline
\end{tabular}


and non-clozapine groups ( $18.4 \%$ vs $17.0 \%$, respectively; $\left.\chi^{2} 0.822 ; \mathrm{df}=1 ; \mathrm{p}=0.364\right)$. The rate of coprescribed sedative-hypnotic treatment was, however, significantly lower for the clozapine compared with the non-clozapine group $\left(10.7 \%\right.$ vs $\left.16.7 \% ; \chi^{2} 17.84 ; \mathrm{df}=1 ; \mathrm{p}<0.001\right)$. Although there was no difference in terms of rates of coprescribed antidepressants (clozapine, $17.4 \%$ vs non-clozapine $16.6 \%$; $\chi^{2}$ $0.35 ; \mathrm{df}=1 ; \mathrm{p}=0.556$ ), there was a trend toward lower rates of mood stabilizer coprescription in the clozapine group $\left(13.7 \%\right.$ vs non-clozapine, $16.7 \% ; \chi^{2} 4.12 ; \mathrm{df}=1 ; \mathrm{p}=$ 0.042).

\section{Discussion}

This retrospective study found that $32.8 \%$ of outpatients diagnosed with schizophrenia or schizoaffective disorder were prescribed clozapine; this is consistent with the expected rate of treatment resistance.

The clozapine-treated group had experienced longer illness duration but overall was not experiencing greater mental or physical health morbidity than was the comparison non-clozapine-treated group. There are 3 findings of particular note. The first of these findings is the lower rates of comorbid neuroleptic-induced movement disorders associated with clozapine treatment. This is consistent with lower rates of extrapyramidal symptoms reported with clozapine, especially when compared with the first-generation antipsychotics and risperidone. ${ }^{1,14,35}$ Second, while it is well documented that clozapine is associated with disorders such as obesity, diabetes, hypertension, and hyperlipidemia, ${ }^{13}$ there also are reports of significant excess mortality and morbidity from cardiovascular disease in schizophrenia patients versus the general population. ${ }^{36-39}$ In this study similar rates of cardiac and endocrine comorbidity were found in both the clozapine and non-clozapine groups $(\sim 8 \%$ and $\sim 10 \%$, respectively). This reflects age-matched cohort studies, which have reported that increased risks may not solely be due to the direct effect of antipsychotics and that these

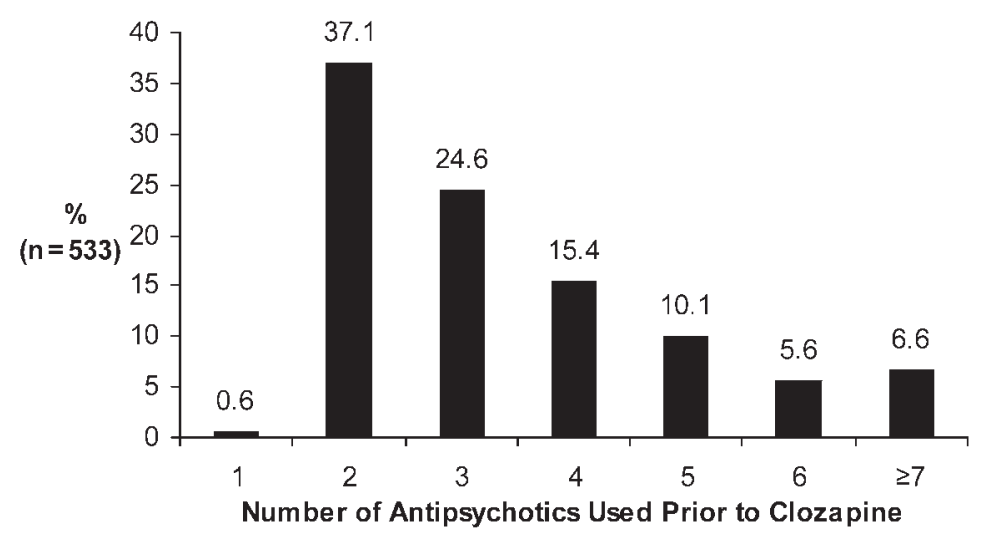

Figure 1. Distribution of schizophrenia outpatients by antipsychotic treatment prior to clozapine. risks are seen with both first- and second-generation antipsychotic treatments. ${ }^{36,39}$ Finally, rates of gastrointestinal comorbidity were higher with clozapine treatment. Constipation is a common problem $(\sim 14 \%)^{14}$ and is likely due to the drug's potent antimuscarinic activity. Other gastrointestinal adverse effects reported with clozapine include heartburn, nausea/ vomiting, and reduced gut motility. ${ }^{14,40}$

The average clozapine dose prescribed in this study (372 mg/day) was within the recommended therapeutic dose range, ${ }^{17,18}$ comparable to that shown in Australian outpatient surveys, ${ }^{41,42}$ and consistent with clinical trial data, ${ }^{43}$ but lower than doses reported in outpatient studies from the US. ${ }^{44}$

On average, it took almost 10 years from first contact with a health provider to starting clozapine treatment. $\mathrm{Pa}$ tients who had a longer delay in treatment were more likely to be older, of European ethnicity, and to have started clozapine when funding was restricted (1993-1998). Almost two-thirds of the patients were started on clozapine after government funding was initiated. On average, they had been prescribed 3 different antipsychotics prior to starting clozapine; for most patients, this included at least one second-generation antipsychotic (91\%). The funding change appears to have been associated with a positive increase in the number of outpatients able to access clozapine for treatment-resistant schizophrenia.

Reassuringly, most outpatients were not sequentially given trials of every second-generation antipsychotic available in New Zealand before being started on clozapine; rather, only $7 \%$ had a treatment history that included all 3 second-generation antipsychotics. This contrasts with reports from the US and China, where clozapine use has decreased as the market share increased with non-clozapine second-generation antipsychotics. ${ }^{21,23,24}$

The duration before clozapine was initiated appears to be significantly delayed. This is concerning in light of evidence-based guidelines recommending early use, the UK long-term effectiveness study CUtLASS 2 (Cost Utility of the Latest Antipsychotic Drugs in Schizophrenia Study), ${ }^{4}$ and emerging research supporting early clozapine treatment in first-episode patients. ${ }^{45}$ The CUtLASS study showed that to achieve a good response at one year in patients who had already failed 2 antipsychotic trials, it was better to commence clozapine than to switch to another second-generation antipsychotic. ${ }^{4}$ In a recently published US study of first-episode patients who had failed to respond to 2 antipsychotics, introducing clozapine (as early as $25 \mathrm{wk}$ into start of treatment) resulted in a better response than switching. The authors suggested that clozapine use should be considered within the first 6 months of schizophrenia treatment and that it should 
be repositioned as a second- rather than third-line treatment. ${ }^{45}$ The issue of earlier use of clozapine was also examined by Kerwin. ${ }^{46} \mathrm{He}$ reviewed arguments for and against earlier clozapine use than its current license allows and concluded that it should be used sooner rather than later and after a single unsuccessful trial of one second-generation antipsychotic.

In a small review of 112 schizophrenia inpatients in the UK, clozapine treatment was found to be delayed an average of up to 5 years. ${ }^{22}$ Five years is shorter than the New Zealand average of 10 years; however, comparing the 2 studies is not possible because of differences in the calculation of treatment

\begin{tabular}{|c|c|c|c|}
\hline \multirow{2}{*}{$\begin{array}{l}\text { Coprescribed } \\
\text { Antipsychotic }\end{array}$} & \multirow[b]{2}{*}{$\mathbf{n}$} & \multicolumn{2}{|c|}{$\begin{array}{l}\text { Clozapine Dose, mg/day } \\
(\text { mean } \pm \text { SD) } n=917\end{array}$} \\
\hline & & Native & CPZe \\
\hline Second-generation & $\mathrm{n}=82$ & & \\
\hline risperidone & 60 & $2.6 \pm 1.7$ & $238 \pm 153$ \\
\hline quetiapine & 16 & $259 \pm 153$ & $173 \pm 102$ \\
\hline olanzapine & 6 & $10.4 \pm 7.8$ & $316 \pm 237$ \\
\hline First-generation oral & $\mathrm{n}=22$ & & \\
\hline chlorpromazine & 7 & $89 \pm 20$ & $89 \pm 20$ \\
\hline haloperidol & 7 & $4.5 \pm 3$ & $225 \pm 150$ \\
\hline trifluoperazine & 3 & $6.8 \pm 9$ & $137 \pm 101$ \\
\hline methotrimeprazine & 2 & $75 \pm 35$ & $75 \pm 35$ \\
\hline zuclopenthixol & 2 & $52.5 \pm 32$ & $210 \pm 128$ \\
\hline thioridazine & 1 & 50 & 50 \\
\hline First-generation depot & $\mathrm{n}=5$ & & \\
\hline fluphenazine & 3 & $\begin{array}{l}12.5 \mathrm{mg} \text {, every } 4 \\
\text { wk for } 2 \text { pts. } \\
37.5 \mathrm{mg} \text {, every } 2 \\
\text { wk for } 1 \text { pt. }\end{array}$ & $200 \pm 216$ \\
\hline flupenthixol & 2 & $\begin{array}{l}40 \mathrm{mg} \text {, every } 2 \text { wk } \\
\text { for both pts. }\end{array}$ & 300 \\
\hline TOTAL & 109 & & \\
\hline
\end{tabular}

delay. Treatment delay in the UK study was calculated from the sixth week of treatment with a second antipsychotic to first use of clozapine and excluded the time before clozapine was available in the UK (pre-1990). If this definition had been applied to the New Zealand data, it would have shortened the calculation, but the degree to which it would have changed the overall result is unknown. However, in line with the findings of this study, the UK study also found that older patients and those diagnosed before the introduction of clozapine had a longer delay in starting clozapine.

Antipsychotic coprescription with clozapine in this study was found to be low $(\sim 12 \%)$. Patients with longer duration before clozapine was initiated were more likely to be coprescribed another antipsychotic, suggesting the existence of a group with a longer history of poor response who were potentially more treatment resistant. When rates of antipsychotic coprescription with clozapine were compared with the rates in the non-clozapine group, they were found to be lower (12\% and 18\%, respectively).

Reported rates of antipsychotic coprescribing with clozapine vary. The cross-sectional rate in this study is comparable to that shown in a Chinese outpatient survey ${ }^{24}$ (13\%) and lower than rates reported in the US (22\% at inpatient discharge, ${ }^{47} 36.2 \%$ polytherapy for $>60$ days, ${ }^{48}$ $21.0 \%$ for polytherapy $>90$ days $^{44}$ ).

There is little evidence to support antipsychotic combinations, but in severe treatment-resistant schizophrenia there are mixed reports supporting clozapine augmentation with another antipsychotic, in particular sulpiride ${ }^{49}$ (not available in New Zealand) and risperidone ${ }^{50-53}$ Outside of this situation, antipsychotic polytherapy is typically recommended for only brief periods of switching, acute relapse, ${ }^{12,54}$ or perhaps for treatment-resistant schizophrenia when clozapine is contraindicated or when a patient refuses. ${ }^{55}$ In this study, just over half of the clozapine coprescribing was with risperidone. This suggests that a number

\begin{tabular}{|c|c|c|c|c|c|c|c|}
\hline \multicolumn{2}{|c|}{ ADR Management, $n(\%)$} & \multicolumn{2}{|c|}{ Sedative-Hypnotic, n (\%) } & \multicolumn{2}{|c|}{ Antidepressant, n (\%) } & \multicolumn{2}{|c|}{ Mood Stabilizer, n (\%) } \\
\hline Benztropine & $135(14.7)$ & Clonazepam & $51(5.6)$ & Paroxetine & $61(6.7)$ & Valproate & $98(10.7)$ \\
\hline Terazosin & $80(8.7)$ & Lorazepam & $25(2.7)$ & Citalopram & $41(4.5)$ & Lithium & 32 (3.5) \\
\hline Procyclidine & $21(2.3)$ & Zopiclone & $18(2.0)$ & Fluoxetine & $35(3.8)$ & & \\
\hline \multirow[t]{9}{*}{ Propranolol } & $5(0.5)$ & Diazepam & $8(0.9)$ & Clomipramine & $8(0.9)$ & & \\
\hline & & Temazepam & $6(0.7)$ & Amitriptyline & $7(0.8)$ & & \\
\hline & & Alprazolam & $1(0.1)$ & Nortriptyline & $6(0.7)$ & & \\
\hline & & & & Imipramine & $2(0.2)$ & & \\
\hline & & & & Moclobemide & $2(0.2)$ & & \\
\hline & & & & Doxepin & $1(0.1)$ & & \\
\hline & & & & Nefazodone & $1(0.1)$ & & \\
\hline & & & & Sertraline & $1(0.1)$ & & \\
\hline & & & & Venlafaxine & $1(0.1)$ & & \\
\hline TOTAL Pts. & $230(25.1)$ & TOTAL Pts. & $98(10.7)$ & TOTAL Pts. & $160(17.4)$ & TOTAL Pts. & $126(13.7)$ \\
\hline
\end{tabular}


of prescribers may have been augmenting a partial response to clozapine; however, it was beyond the scope of this study to examine clinical indications for coprescribing. Some practices observed have no evidence to support coprescribing; multiple $(>2)$ antipsychotics and combinations including a depot antipsychotic should be avoided because of the risk of prolonged bone marrow suppression. ${ }^{17,18}$

This study also found that schizophrenia patients, irrespective of whether they were treated with clozapine or alternative antipsychotic(s), were prescribed an average of only 2 psychotropics, including the antipsychotic. This is possibly due to low rates of comorbid mental illness reported in both treatment groups $(20 \%$ and $25 \%$, respectively). A slightly higher number of psychopharmacologic medications (average of 3) were reported in a US study of schizophrenia patients in routine practice; $41 \%$ of this group had comorbid mental illness. ${ }^{56}$

Most commonly coprescribed psychotropics in this review were for the management of adverse effects, $25 \%$ of the clozapine group compared with $19 \%$ in the non-clozapine group. Terazosin and benztropine have been reported to be effective in the management of clozapine-induced hypersalivation, ${ }^{57}$ which occurs in approximately $30 \%$ of patients. ${ }^{14}$ With non-clozapine antipsychotics, anticholinergics are recommended most commonly for the management of acute extrapyramidal symptoms. About $11 \%$ of the clozapine group was coprescribed a sedative-hypnotic, which was lower than the rate for the non-clozapine group (17\%). A possible explanation is that sedation is the most commonly reported adverse effect caused by clozapine's pharmacologic profile $(\sim 39 \%) .{ }^{14}$ Clonazepam, a long-acting benzodiazepine, was the most frequently coprescribed sedative-hypnotic. This may be explained by augmentation of clozapine partial responders (psychotic agitation, irritability, anxiety), ${ }^{58}$ rather than use as a sedative-hypnotic. Concomitant antidepressants and mood stabilizers were prescribed for less than $20 \%$ of both treatment groups, and there was no significant difference in the rates between groups.

\section{LIMITATIONS}

The findings of this study represent real-world prescribing for all schizophrenia patients attending a CMHC in Auckland and Northland. It reflects the total antipsychotic regimen that the prescriber intended the patient to take at the time of the review; however, the study did not explore adherence to or the clinical effects of treatment. The methodology employed cross-sectional data that were documented in the outpatient clinical records and collected retrospectively. Therefore, the quality of the study data was dependent to a large extent on the quality of the clinical recordings made by the mental health clinicians. It was beyond the scope of this study to examine whether patients were ever offered clozapine and reasons why prescribers may or may not have recommended a clozapine trial or why patients may or may not have agreed to such a trial.

The study findings may not be generalizable to other settings, such as elderly services or primary care; however, the findings reflect antipsychotic prescribing by more than 50 prescribers for approximately one-third of adult outpatients with schizophrenia or schizoaffective disorder living in New Zealand.

\section{Conclusions}

This study suggests that patients with treatment-resistant schizophrenia were able to access clozapine, but its use was delayed in many. It appears that younger patients with shorter treatment histories were prescribed clozapine earlier. Access to clozapine may have been supported by the increase in funding, publication of guidelines, and increasing clinician experience with the agent over time. In routine practice, where there were no restrictions on concomitant prescribing, low rates were found, typically consisting of the antipsychotic and another medication to treat its adverse effects. These findings have been presented to clinicians as part of the audit cycle feedback in an effort to reinforce best-practice and increase appropriate adherence to best-practice recommendations. Further work supporting earlier clozapine initiation, especially in the community setting, is ongoing. Other initiatives to address some of the potential barriers to early use of clozapine include assertive community treatment teams to assist with supervised medication administration and use of other healthcare and service providers, such as primary care and residential rehabilitation, to assist in monitoring while treatment is initiated.

Amanda J Wheeler PGDipPsychPharm MRPharmS MPS(NZ), Director, Clinical Research and Resource Centre, Waitemata District Health Board; Senior Clinical Lecturer, School of Medical and Health Sciences, University of Auckland, Auckland, NZ

Reprints: Ms. Wheeler, Mental Health and Addiction Services, Snelgar Building, Waitakere Hospital, Waitemata District Health Board, 5575 Lincoln Rd., Waitakere, Auckland, New Zealand, fax 098381883 , amanda.wheeler@waitematadhb.govt.nz

This study was supported by unconditional research grants from the 4 District Health Boards, Eli Lilly and Company (NZ) Ltd, AstraZeneca NZ Ltd, and Janssen-Cilag NZ Ltd.

I appreciate the assistance of the Mental Health Services and staff at the 4 DHBs. I thank Kirsten Norris, Morgan Kelly, and Karen Day for data collection and entry, Dr. Grant Paton-Simpson for database support, Elizabeth Robinson for statistical advice, and Prof. Peter Joyce for support and feedback.

\section{References}

1. Wahlbeck K, Cheine M, Essali MA. Clozapine versus typical neuroleptic medication for schizophrenia. Cochrane Database Syst Rev 2000: CD000059.

2. Meltzer HY, Bastani B, Kwon KY, Ramirez LF, Burnett S, Sharpe J. A prospective study of clozapine in treatment-resistant schizophrenic patients. Psychopharmacology 1989;99(suppl):S68-72.

3. Davis JM, Chen N, Glick ID. A meta-analysis of the efficacy of secondgeneration antipsychotics. Arch Gen Psychiatry 2003;60:553-64. 
4. Lewis SW, Barnes TRE, Davies L, et al. Randomized controlled trial of effect of prescription of clozapine versus other second-generation antipsychotic drugs in resistant schizophrenia. Schizophr Bull 2006;32: 715-23.

5. McEvoy JP, Lieberman JA, Stroup TS, et al. Effectiveness of clozapine versus olanzapine, quetiapine, and risperidone in patients with chronic schizophrenia who did not respond to prior atypical antipsychotic treatment. Am J Psychiatry 2006;163:600-10.

6. Kane J, Honigfeld G, Singer J, Meltzer H. Clozapine for the treatmentresistant schizophrenic: a double-blind comparison with chlorpromazine. Arch Gen Psychiatry 1988;45:789-96.

7. Hennen J, Baldessarini RJ. Suicidal risk during treatment with clozapine: a meta-analysis. Schizophr Res 2005;73:139-45.

8. Morris S, Hogan T, McGuire A. The cost-effectiveness of clozapine: a survey of the literature. Clin Drug Invest 1998;15:137-52.

9. Reid WH, Mason M. Psychiatric hospital utilization in patients treated with clozapine for up to 4.5 years in a state mental health care system. $\mathrm{J}$ Clin Psychiatry 1998;59:189-94.

10. Practice guideline for the treatment of patients with schizophrenia. 2nd ed. Washington, DC: American Psychiatric Association, 2004.

11. National Institute for Clinical Evidence (NICE). Guidance on the use of newer (atypical) antipsychotic drugs for the treatment of schizophrenia. London: National Institute for Clinical Evidence, 2002.

12. Royal Australian and New Zealand College of Psychiatrists Clinical Practice Guidelines Team for Schizophrenia and Related Disorders. Royal Australian and New Zealand College of Psychiatrists clinical practice guidelines for the treatment of schizophrenia and related disorders. Aust N Z J Psychiatry 2005;39:1-30.

13. Henderson DC, Nguyen DD, Copeland PM, et al. Clozapine, diabetes mellitus, hyperlipidemia, and cardiovascular risks and mortality: results of a 10-year naturalistic study. J Clin Psychiatry 2005;66:1116-21.

14. Safferman A, Lieberman JA, Kane JM, Szymanski S, Kinon B. Update on the clinical efficacy and side effects of clozapine. Schizophr Bull 1991;17:247-61.

15. Killian JG, Kerr K, Lawrence C, Celermajer DS. Myocarditis and cardiomyopathy associated with clozapine. Lancet 1999;354:1841-5.

16. La Grenade L, Graham D, Trontell A. Myocarditis and cardiomyopathy associated with clozapine use in the United States. N Engl J Med 2001; 345:224-5

17. Douglas Pharmaceuticals Ltd. Data sheet: Clopine. Wellington, NZ: New Zealand Medicines and Medical Devices Safety Authority, Ministry of Health, October 4, 2007.

18. Novartis New Zealand Ltd. Data sheet: Clozaril. Wellington, NZ: New Zealand Medicines and Medical Devices Safety Authority, Ministry of Health, October 4, 2007.

19. New Zealand Mental Health Metabolic Working Group. A New Zealand Mental Health Metabolic Working Group Initiative. Auckland, NZ: Janssen Cilag Ltd, 2006.

20. Duggan A, Warner J, Knapp M, Kerwin R. Modelling the impact of clozapine on suicide in patients with treatment-resistant schizophrenia in the UK. Br J Psychiatry 2003;182:505-8.

21. Weissman EM. Antipsychotic prescribing practices in the Veterans Healthcare Administration-New York metropolitan region. Schizophr Bull 2002;28:31-42.

22. Taylor DM, Young C, Paton C. Prior antipsychotic prescribing in patients currently receiving clozapine: a case note review. J Clin Psychiatry 2003;64:30-4

23. Essock SM. Antipsychotic prescribing practices. Schizophr Bull 2002; 28:1-4.

24. Xiang YT, Weng YZ, Leung CM, Tang WK, Ungvari GS. Clinical correlates of clozapine prescription for schizophrenia in China. Hum 2007; 22:17-25.

25. Mahy P. A bitter pill? North \& South 1995:88-95.

26. Mental Health Commission. New Zealand's National Mental Health Strategy; review of progress 1994-1999. Wellington, NZ: Mental Health Commission, 1999.

27. Ministry of Health. Toward clinical excellence; an introduction to clinical audit, peer review and other clinical practice improvement activities.
Wellington, NZ: Ministry of Health, 2002. www.moh.govt.nz/moh.nsf/ pagesmh/334? Open (accessed 2007 Oct 4).

28. Walker RA. 2001 Demographic profile for Auckland District Health Board: an analysis of 2001 Census. Auckland, NZ: Regional Decision Support Team, Northern DHB Support Agency (NDSA), 2002.

29. Walker RA. 2001 Demographic profile for counties Manukau District Health Board: an analysis of 2001 Census. Auckland, NZX: Regional Decision Support Team, Northern DHB Support Agency (NDSA), 2002.

30. Walker RA. 2001 Demographic profile for Northland District Health Board: an analysis of 2001 Census. Auckland, NZ: Regional Decision Support Team, Northern DHB Support Agency (NDSA), 2002.

31. Walker RA. 2001 Demographic profile for Waitemata District Health Board: an analysis of 2001 Census. Auckland, NZ: Regional Decision Support Team, Northern DHB Support Agency (NDSA), 2002.

32. Diagnostic and statistical manual of mental disorders. 4th ed. Washington, DC: American Psychiatric Association, 1994.

33. Humberstone V, Wheeler A, Lambert T. An audit of outpatient antipsychotic usage in the three health sectors of Auckland, New Zealand. Aust N Z J Psychiatry 2004;38:240-5.

34. Praharaj SK, Arora M, Gandotra S. Clozapine-induced sialorrhea: pathophysiology and management strategies. Psychopharmacology 2006;185: 265-73.

35. Tuunainen A, Wahlbeck K, Gilbody S. Newer atypical antipsychotic medication in comparison to clozapine: a systematic review of randomized trials. Schizophr Res 2002;56:1-10.

36. Enger C, Weatherby L, Reynolds RF, Glasser DB, Walker AM. Serious cardiovascular events and mortality among patients with schizophrenia. J Nerv Ment Dis 2004;192:19-27.

37. Hennekens CH, Hennekens AR, Hollar D, Casey DE. Schizophrenia and increased risks of cardiovascular disease. Am Heart J 2005;150:1115-21.

38. Lambert TJR, Velakoulis D, Pantelis C. Medical comorbidity in schizophrenia. Med J Aust 2003;178:s67-s70.

39. Osborn DP, Levy G, Nazareth I, Petersen I, Islam A, King MB. Relative risk of cardiovascular and cancer mortality in people with severe mental illness from the United Kingdom's General Practice Research Database. Arch Gen Psychiatry 2007;64:242-9.

40. Ellis PM, Mclean RM, Harrison-Woolrych M. Clozapine: fatal 'constipation' more common than fatal agranulocytosis. Medsafe Prescriber Update 2007;28:7. www.medsafe.govt.nz/Profs/PUArticles/clozGI.htm (accessed 2007 Oct 4).

41. Conley RR, Kelly DL, Lambert TJ, Love RC. Comparison of clozapine use in Maryland and in Victoria, Australia. Psychiatr Serv 2005;56:320-3.

42. Keks NA, Altson K, Hope J, et al. Use of antipsychosis and adjunctive medications by an inner urban community psychiatric service. Aust N Z J Psychiatry 1999;33:896-901.

43. Fleischhacker WW, Hummer M, Kurz M, et al. Clozapine dose in the United States and Europe: implications for therapeutic and adverse effects. J Clin Psychiatry 1994;55:78-81.

44. Kreyenbuhl JA, Valenstein M, McCarthy JF, Ganoczy D, Blow FC. Long-term antipsychotic polypharmacy in the VA health system: patient characteristics and treatment patterns. Psychiatr Serv 2007;58:489-95.

45. Agid O, Remington G, Kapur S, Arenovich T, Zipursky RB. Early use of clozapine for poorly responding first-episode psychosis. J Clin Psychopharmacol 2007;27:369-73.

46. Kerwin R. When should clozapine be initiated in schizophrenia? Some arguments for and against earlier use of clozapine. CNS Drugs 2007;21: 267-78.

47. Procyshyn RM, Kennedy NB, Tse G, Thompson B. Antipsychotic polypharmacy: a survey of discharge prescriptions from a tertiary care psychiatric institution. Can J Psychiatry 2001;46:334-9.

48. Ganguly R, Kotzan JA, Miller LS, Kennedy K, Martin BC. Prevalence, trends, and factors associated with antipsychotic polypharmacy among Medicaid-eligible schizophrenia patients, 1998-2000. J Clin Psychiatry 2004;65:1377-88.

49. Shiloh R, Zemishlany Z, Aizenberg D, et al. Sulpiride augmentation in people with schizophrenia partially responsive to clozapine. A doubleblind, placebo-controlled study. Br J Psychiatry 1997;171:569-73. 
50. Josiassen RC, Joseph A, Kohegyi E, et al. Clozapine augmented with risperidone in the treatment of schizophrenia: a randomized, doubleblind, placebo-controlled trial. Am J Psychiatry 2005;162:130-6.

51. Honer WG, Thornton AE, Chen EY, et al. Clozapine alone versus clozapine and risperidone with refractory schizophrenia. N Engl J Med 2006; 354:472-82.

52. Anil Yaciolu AE, Kivircik Akdede BB, Turgut TI, et al. A double-blind controlled study of adjunctive treatment with risperidone in schizophrenic patients partially responsive to clozapine: efficacy and safety. J Clin Psychiatry 2005;66:63-72.

53. Freudenreich O, Henderson DC, Walsh JP, Culhane MA, Goff DC. Risperidone augmentation for schizophrenia partially responsive to clozapine: a double-blind, placebo-controlled trial. Schizophr Res 2007; 92:90-4.

54. National Collaborating Centre for Mental Health. Schizophrenia: core interventions in the treatment of schizophrenia in primary and secondary care. Clinical guideline 1. London: National Institute for Clinical Excellence, 2002.

55. Miller AL, Hall CS, Buchanan RW, et al. The Texas Medication Algorithm Project antipsychotic algorithm for schizophrenia: 2003 update. J Clin Psychiatry 2004;65:500-8.

56. West JC, Wilk JE, Olfson M, et al. Patterns and quality of treatment for patients with schizophrenia in routine psychiatric practice. Psychiatr Serv 2005;56:283-91.

57. Reinstein MJ, Sirotovskaya LA, Chasanov MA, Jones LE. Comparative efficacy and tolerability of benztropine and terazosin in the treatment of hypersalivation secondary to clozapine. Clin Drug Investig 1999;17:97-102.

58. Remington G, Saha A, Chong SA, Shammi C. Augmentation strategies in clozapine-resistant schizophrenia. CNS Drugs 2005;19:843-72.

Tratamiento y Perfil de Prescripción de la Esquizofrenia en Nueva Zelanda

AJ Wheeler

Ann Pharmacother 2008;42:852-60.

\section{EXTRACTO}

OBJETIVO: Describir el tratamiento y el perfil de utilización de la clozapina en la esquizofrenia, incluyendo la prescripción asociada a otros psicofármacos, comparando el grado de prescripción asociada entre pacientes esquizofrénicos tratados o no con clozapina y atendidos en los centros de salud mental de las regiones de Auckland y Northland de Nueva Zelanda.

MÉTODo: Se realizó una revisión retrospectiva de las historias clínicas de los pacientes adultos que eran atendidos en los centros de salud mental de octubre el 31 de 2004. Los datos recogidos para todos los pacientes a los que se les prescribió un antipsicótico incluían variables demográficas (género, edad, etnia), diagnóstico principal DSM-IV, comorbillidad, duración de la enfermedad mental, ingresos psiquiátricos, e información sobre tratamientos (psicofármacos, dosis, y vía de administración). Allí donde se inició tratamiento con clozapina, después de la introducción de un subsidio gubernamental de la totalidad de la prescripción (febrero 1999), se añadieron datos adicionales como el año de inicio y la historia previa de utilización de antipsicóticos. El análisis incluyó todos los pacientes externos con diagnóstico de esquizofrenia (incluyendo los trastornos psicoafectivos).

RESULTADOS: Se prescribieron antipsicóticos a un total de 2796 pacientes; se prescribió clozapina a un 32.8\% de estos, a una dosis media de 372 $\mathrm{mg} / \mathrm{dí}$, con un promedio de duración de la enfermedad de 9.7 años antes de iniciar la clozapina. El 59\% iniciaron el tratamiento con clozapina después de que fuera financiada por el gobierno y presentan una media de utilización de 3 antipsicóticos, antes de iniciar la clozapina. Muchos utilizaron un antipsicótico de segunda generación (91\%). Los pacientes con clozapina presentaban menor probabilidad de utilizar otro antipsicó- tico comparado con los que no utilizaban la clozapina (12\% vs $18 \%$; $\mathrm{p}<$ 0.001). Tanto el grupo de clozapina como el de no clozapina, tenían un número total de antipsicóticos prescritos bajo $($ media $=2)$. Para la clozapina, el segundo medicamento fue sobre todo para la hipersalivación.

CONCLUSIONES: Los pacientes externos con esquizofrenia resistente acceden a la clozapina en la proporción prevista; sin embargo el tratamiento se retrasó más de lo recomendado. Existe alguna evidencia de la mejora en el acceso a la clozapina para el tratamiento de la esquizofrenia resistente, posiblemente como resultado de la introducción de la financiación del gobierno, de la difusión de las guías o por la mayor experiencia de los clínicos. En este entorno, el número de fármacos asociados a los antipsicóticos para los pacientes externos con esquizofrenia fue bajo, y en el caso de la clozapina, fue habitualmente para tratar los efectos adversos.

Traducido por Corinne Zara Yahni

L'utilisation de la Clozapine pour le Traitement de la Schizophrénie en Nouvelle-Zélande

\section{AJ Wheeler}

Ann Pharmacother 2008;42:852-60.

\section{RÉSUMÉ}

OBJECTIF: Décrire les différents modes d'utilisation de la clozapine pour le traitement de la schizophrénie, incluant la co-prescription de psychotropes et comparer l'étendue de la co-prescription de psychotropes chez les patients schizophrènes non traités par la clozapine et suivis par les services de santé mentale à la communauté dans les régions d'Auckland et du nord de la Nouvelle-Zélande (Northland).

MÉTHODOLOGIE: Une étude rétrospective des dossiers a été faite chez des patients adultes recevant des soins des Services de santé mentale octobre 31, 2004. Les données suivantes ont été colligées pour tous les patients chez qui un antipsychotique a été prescrit: genre, âge, ethnicité,

diagnostic selon le DSM-IV, co-morbidité, début d'apparition de la condition, hospitalisations en milieu psychiatrique, et information sur le traitement pharmacologique (médicament, posologie, et voie d'administration). Lorsque la clozapine a été prescrite après l'introduction du programme d'accès gratuit à la clozapine (février 1999), l'année du début de traitement ainsi que la médication psychotrope antérieure sont des données additionnelles disponibles. L'analyse inclut tous les patients pour lesquels un diagnostic de schizophrénie a été fait, incluant les troubles schizo-affectifs.

RÉSULTATS: Des antipsychotiques ont été prescrits chez 2796 schizophrènes pendant la période étudiée; $32.8 \%$ recevaient de la clozapine (dose moyenne de $372 \mathrm{mg} / \mathrm{jour}$ ), et la condition était présente depuis 9.7 ans en moyenne avant le début du traitement par la clozapine. Cinquanteneuf pour cent de ces patients ont débuté la clozapine après la mise sur pied du programme gouvernemental d'accès gratuit et avaient reçu 3 médicaments psychotropes (médiane) avant de débuter la clozapine, dont un antipsychotique de deuxième génération dans $91 \%$ des cas. Chez les patients recevant la clozapine, moins de co-prescription d'antipsychotiques a été observée ( $12 \%$ vs 18\%; p < 0.001). Dans les 2 groupes (avec ou sans clozapine), on a observé un faible nombre de médicaments psychotropes (médiane $=2$ ); dans le groupe ayant reçu la clozapine, le deuxième médicament était le plus souvent ajouté pour contrôler l'hypersalivation. CONCLUSIONS: Les patients ambulatoires présentant une schizophrénie réfractaire ont eu accès à la clozapine selon les prévisions; cependant, le début du traitement était retardé par rapport aux recommandations. L'accès à la clozapine dans les cas résistants s'est amélioré, possiblement en raison de la mise sur pied du programme d'accès gouvernemental, de la publication de lignes directrices de traitement, et d'une expertise clinique plus grande avec la clozapine. En milieu réel, le nombre de coprescriptions de psychotropes est faible et, pour le groupe recevant de la clozapine, la co-prescription servait surtout à contrôler les effets indésirables du médicament.

Traduit par Denyse Demers 